\title{
MODEL PEMBELAJARAN KOOPERATIF TIPE TEAMS-GAMES- TOURNAMENTS UNTUK PENCAPAIAN KEMAMPUAN PEMAHAMAN KONSEP MATEMATIKA SISWA
}

\author{
Euis Anih ${ }^{1}$, Nurlaela ${ }^{2}$ \\ 1,2 STKIP Subang
}

\begin{abstract}
The ability to understand concepts is one of the curriculum demands that needs to be achieved. The lack of understanding and mastery of mathematical concepts, one of which is caused by factors students only memorize concepts not understood and the methods used by teachers in learning seem less fun even boring. Through the Teams Geams Tournaments type of cooperative learning model students are expected to not only memorize mathematical concepts but really understand the concepts being studied. This study was conducted with the aim to: 1) find out the achievement of students' understanding of mathematical concepts after using the TGT cooperative type better than those using conventional learning methods, 2) know the increase in understanding of mathematical concepts of students who get learning with the TGT type cooperative model and who obtain learning conventional, 3) knowing students' responses to learning by using TGT type cooperative learning. Data was collected from the ability test of students' understanding of mathematical concepts in the form of question and student questionnaire. Questionnaires were given to all students of the experimental class with the aim of knowing students' responses to mathematics learning by using TGT type cooperative learning. This research is a quasi-experimental research with experimental class design that is Pretest-Treatment-Posttest while the control class is Pretest-Posttest. From the results of data analysis with a significant level $\alpha=0.05$ shows that the achievement of the ability to understand mathematical concepts of students who get cooperative learning with TGT type is better than conventional learning. Improved understanding of mathematical concepts of students who get cooperative learning with TGT type is better than the ability to understand mathematical concepts of students who get conventional learning. Improved understanding of mathematical concepts of students who get cooperative learning with TGT type included in the medium category, while students who get conventional learning increased in the low category. Based on the analysis of students' responses to the TGT type of cooperative learning shows that students are positive about mathematics learning with the TGT type of cooperative.
\end{abstract}

Keywords: Cooperative Learning Type TGT, Ability to Understand Mathematical Concepts.

\begin{abstract}
ABSTRAK
Kemampuan pemahaman konsep merupakan salah satu tuntutan kurikulum yang perlu dicapai. Rendahnya pemahaman dan penguasaan konsep-konsep matematika salah satunya disebabkan oleh faktor siswa hanya menghafal konsep bukan dipahami dan metode yang digunakan guru dalam pembelajaran terkesan
\end{abstract}


kurang menyenangkan bahkan membosankan. Melalui model pembelajaran kooperatif tipe Teams Geams Tournaments siswa diharapkan tidak hanya menghafal konsep matematika tetapi betul-betul memahami konsep yang sedang dipelajari. Penelitian ini dilaksanakan dengan tujuan untuk: 1) mengetahui pencapaian kemampuan pemahaman konsep matematika siswa setelah menggunakan kooperatif tipe TGT lebih baik daripada yang menggunakan pembelajaran cara konvensional, 2) mengetahui peningkatan pemahaman konsep matematika siswa yang memperoleh pembelajaran dengan model kooperatif tipe TGT dan yang memperoleh pembelajaran konvensional, 3) mengetahui respon siswa terhadap pembelajaran dengan menggunakan pembelajaran kooperatif tipe TGT. Data dikumpulkan dari tes kemampuan pemahaman konsep matematika siswa berupa soal uraian dan angket siswa. Angket diberikan kepada seluruh siswa kelas eksperimen dengan tujuan untuk mengetahui respon siswa terhadap pembelajaran matematika dengan menggunakan pembelajaran kooperatif tipe TGT. Penelitian ini merupakan penelitian kuasi eksperimen dengan desain kelas eksperimen yaitu Pretes-Treatment-Postest sedangkan kelas kontrol yaitu PretestPostest. Dari hasil analisis data dengan taraf signifikan $\alpha=0,05$ menunjukan bahwa pencapaian kemampuan pemahaman konsep matematika siswa yang mendapatkan pembelajaran dengan kooperatif tipe TGT lebih baik dibandingkan dengan pembelajaran konvensional. Peningkatan pemahaman konsep matematika siswa yang mendapatkan pembelajaran matematika dengan kooperatif tipe TGT lebih baik dibandingkan dengan kemampuan pemahaman konsep matematika siswa yang mendapatkan pembelajaran konvensional. Peningkatan pemahaman konsep matematika siswa yang mendapatkan pembelajaran matematika dengan kooperatif tipe TGT teramasuk kategori sedang, sedangkan siswa yang mendapatkan pembelajaran konvensional peningkatannya termasuk kategori rendah. Berdasarkan hasil analisis respon siswa terhadap pembelajaran kooperatif tipe TGT menunjukan bahwa siswa bersikap positif terhadap pembelajaran matematika dengan kooperatif tipe TGT.

Kata Kunci : Pembelajaran Kooperatif Tipe TGT, Kemampuan Pemahaman Konsep Matematika.

\section{A. Pendahuluan}

Matematika adalah salah satu ilmu dasar, baik aspek terapannya maupun aspek penalarannya, mempunyai peranan yang penting dalam upaya penguasaan ilmu dan teknologi. Dengan demikian, matematika perlu dikuasai oleh segenap warga negara Indonesia baik penerapannya maupun pola pikirnya. Pendidikan matematika merupakan wahana untuk mengembangkan semua potensi yang dimiliki siswa termasuk kemampuan bernalar, 
kreativitas, kemampuan memecahkan masalah, kebiasaan kerja keras dan mandiri, jujur, berdisiplin, memiliki sikap sosial yang baik serta berbagai keterampilan dasar yang diperlukan dalam hidup bermasyarakat.

Kompetensi dasar yang harus dicapai setiap peserta didik dapat diukur dan diamati berdasarkan indikator pembelajaran. Indikator pembelajaran akan dicapai dan dikuasai melalui pengalaman pembelajaran. Peran guru hanya sebagai fasilitator dalam proses pembelajaran.

Berkaitan dengan pendidikan matematika sampai saat ini pembelajaran matematika di sekolah, masih banyak menggunakan pendekatan yang kurang melibatkan aktifitas siswa secara optimal dalam pembelajaran sehingga siswa kurang aktif dalam belajar. Dalam kenyataannya dilapangan justru pencapaian siswa pasif dalam merespon proses pembelajaran. Siswa pada umumnya bahkan cenderung hanya menerima transfer ilmu pengetahuan dari guru. Sebagian besar guru pada waktu kegiatan pembelajaran hanya sekedar menyampaikan informasi ilmu pengetahuan tanpa melibatkan siswa dalam proses yang aktif dan generatif. Hal tersebut yang menyebabkan siswa hanya menerima sesuatu tetapi siswa kurang mampu untuk menjelaskan unsur-unsur apa yang membangun sesuatu itu, yang akhirnya kemampuan memahami konsep matematika menjadi lemah. Rendahnya pemahaman dan penguasaan konsep-konsep matematika salah satunya disebabkan oleh faktor siswa hanya menghafal konsep matematika yang dipelajari bukan dipahami dan metode yang digunakan guru dalam pembelajaran terkesan kurang menyenangkan bahkan membosankan.

Kemampuan pemahaman konsep (conceptual understanding) merupakan salah satu tuntutan kurikulum yang perlu dicapai. Kemampuan ini sangat berguna dalam menyelesaikan suatu permasalahan dalam pembelajaran matematika baik yang bersifat konsep maupun konteks. Dalam proses pembelajaran, guru sangat memegang peranan penting, oleh karena itu guru memiliki tanggung jawab terhadap ketercapaian tujuan pembelajaran. Salah satu kewajiban 
guru adalah memiliki kemampuan dalam memilih model pembelajaran yang tepat sehinnga tujuan bisa tercapai. Salah satu model pembelajaran yang bisa digunakan untuk menyelesaikan masalah di atas saat ini adalah model pembelajaran kooperatif tipe Teams Geams Tournaments.

Pembelajaran kooperatif tipe TGT adalah salah satu metode pembelajaran kooperatif yang mudah diterapkan, melibatkan aktivitas seluruh siswa tanpa harus ada perbedaan status, melibatkan peran siswa sebagai tutor sebaya dan mengandung unsur permainan. Aktivitas belajar dengan permainan yang dirancang dalam pembelajaran kooperatif tipe TGT memungkinkan siswa dapat belajar lebih rileks disamping menumbuhkan tanggung jawab, kerja sama, persaingan sehat dan keterlibatan belajar (Mulyani, 2006).

Pembelajaran kooperatif tipe TGT terdiri dari lima komponen utama, yaitu : presentasi di kelas, tim (kelompok), game (permainan), turnamen (pertandingan), dan rekognisi tim (perhargaan kelompok). Prosedur pelaksanaan TGT dimulai dari aktivitas guru dalam menyampaikan pelajaran secara singkat tentang materi yang akan dipelajari, kemudian siswa bekerja dalam tim mereka untuk memastikan bahwa semua anggota tim telah menguasai pelajaran. Setelah membuat tim dan setiap tim diberikan Lembar Kerja Siswa (LKS) kemudian setiap siswa menjawab soal yang ada di LKS. Setelah siswa dipastikan sudah menjawab soal di dalam LKS kemudian guru menyiapkan soal-soal berbentuk kuis atau pertanyaan tentang materi yang sedang dipelajari dan guru memanggil perwakilan setiap kelompok untuk menjawab kuis. Selanjutnya diadakan turnamen yang biasanya dilaksanakan pada akhir pembelajaran setelah semua materi dipelajari, pada saat turnamen siswa memainkan game akademik dengan anggota tim lain untuk menyumbangkan poin bagi skor timnya.

Berdasarkan pemaparan di atas, untuk mengetahui seberapa besuhar pengaruh model pembelajaran kooperatif tipe Teams Geams Tournaments terhadap capaian kemampuan pemahaman konsep matematika siswa maka perlu diteliti 
hal-hal sebagai berikut : (1) Apakah pencapaian kemampuan pemahaman konsep matematika siswa yang menggunakan model pembelajaran kooperatif tipe TGT lebih baik daripada yang menggunakan cara konvensional ? (2) Bagaimana peningkatan pemahaman konsep matematika siswa yang memperoleh pembelajaran dengan model kooperatif tipe TGT dan yang memperoleh pembelajaran konvensional? (3) Bagaimana respon siswa terhadap pembelajaran matematika dengan menggunakan model pembelajaran kooperatif tipe TGT ?

\section{B. Metode Penelitian}

Metode yang digunakan dalam penelitian ini adalah metode penelitian quasi eksperimen dengan menggunakan desain kelompok eksperimen dan kontrol adanya pretes dan postes yang melibatkan dua kelompok tersebut. Penelitian quasi eksperimen ini dia mbil berdasarkan teori dari pendapat beberapa para ahli, Stouffer dan Campbell (Rakhmasari, 2010) merumuskan eksperimen quasi (quasi experiment) sebagai eksperimen yang memiliki perlakuan, pengukuran dampak, unit eksperiman, namun tidak menggunakan penugasan acak untuk menciptakan pembandingan dalam rangka menyimpulkan perubahan yang disebabkan perlakuan.

$$
\text { Salah satu syarat yang }
$$
dipenuhi dalam penelitian kuasi eksperimen ini adalah melakukan pengukuran sebagai hasil eksperimen terhadap variabel terikatnya (kemampuan pemahaman konsep). Dalam penelitian ini terdapat dua kelompok penelitian yaitu kelompok eksperimen dan kelompok kontrol. Kelompok eksperimen adalah kelompok yang memperoleh perlakuan pelajaran matematika dengan menggunakan model kooperatif tipe Teams Games Tournaments (TGT), sedangkan kelompok kontrol adalah kelompok yang memperoleh perlakuan pembelajaran matematika konvensional.

Dalam penelitian ini dan masalah yang dikatakan sebelumnya, maka desain penelitian ini pada jenis desain kuasi eksperimen ini subyek tidak diambil secara acak, adanya pretes $(\mathrm{O})$ dan postes $(\mathrm{O})$, pada kelas 
eksprimen terdapat perlakuan $(X)$ pembelajaran kooperatif tipe TGT, dengan gambar kuasi eksperimennya sebagai berikut:

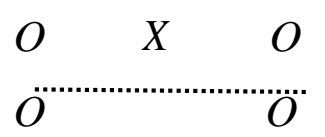

Keterangan:

$\mathrm{O}=$ Pretes dan postes

$\mathrm{X}=$ Perlakuan pembelajaran matematika menggunakan model kooperatif tipe Teams Geams Tournaments (TGT)

\section{Hasil Penelitian dan Pembahasan}

Beberapa tes yang dilakukan dalam penelitian ini adalah Tes awal dan tes akhir. Tes awal dilakukan untuk mengetahui kemampuan awal siswa sebelum mendapatkan pengajaran, baik di kelas eksperimen ataupun di kelas kontrol, sementara tes akhir (posttest) dilakukan untuk mengatahui tingkat pencapaian kemampuan pemahaman konsep matematika siswa setelah mendapatkan proses pembelajaran. Berdasarkan hasil penelitian mengenai kemampuan siswa sebelum dilaksanakannya proses pembelajaran, yaitu pembelajaran matematika dengan model kooperatif tipe TGT pada kelas eksperimen, serta pembelajaran matematika dengan cara konvensional pada kelas kontrol bisa dilihat seperti pada Tabel 1.

Tabel 1

Hasil Tes Awal Pada Kelas Eksperimen dan Kelas Kontrol

\begin{tabular}{|l|l|l|l|}
\hline \multicolumn{1}{|c|}{ Kelas } & \multicolumn{1}{c|}{ Jumlah Siswa } & \multicolumn{1}{c|}{ Rata-rata } & \multicolumn{1}{c|}{ Standar Deviasi } \\
\hline Eksperimen & 37 & 35,9 & 11 \\
\hline Kontrol & 37 & 32,5 & 8,9 \\
\hline
\end{tabular}

Setelah dilaksanakan proses pembelajaran dengan memberikan perlakuan yang berbeda diantara kedua kelas tersebut. Perlakuan dengan pembelajaran matematika menggunakan model kooperatif tipe
TGT pada kelas eksperimen dan pembelajaran dengan cara konvensional pada kelas kontrol, yang kemudian diakhiri dengan pemberian tes akhir yang mana instrumennya sama dengan soal tes awal. Hasil dari 
tes akhir pada kedua kelas bisa dilihat seperti pada Tabel 2.

Tabel 2 Hasil Tes Akhir pada

Kelas Eksperimen dan Kelas Kontrol

\begin{tabular}{|l|c|c|c|}
\hline \multicolumn{1}{|c|}{ Kelas } & Jumlah Siswa & Rata-rata & Standar Deviasi \\
\hline Eksperimen & 37 & 67,06 & 11,8 \\
\hline Kontrol & 37 & 53,22 & 8,8 \\
\hline
\end{tabular}

Berdasarkan hasil tes awal dan tes akhir pada kedua sampel penelitian, baik kelas eksperimen maupun kelas kontrol. Diperoleh skor tes pencapaian kemampuan pemahaman konsep matematika siswa yang bisa dilihat seperti pada Tabel 3.

Tabel 3

Rekapitulasi Hasil Tes Awal dan Tes Akhir

\begin{tabular}{|l|l|l|l|l|}
\hline \multirow{2}{*}{ Uraian Data } & \multicolumn{2}{|l|}{ Tes Awal } & Tes Akhir \\
\cline { 2 - 5 } & $\begin{array}{l}\text { Kelas } \\
\text { Eksperimen }\end{array}$ & $\begin{array}{l}\text { Kelas } \\
\text { Kontrol }\end{array}$ & Kelas Eksperimen & Kelas Kontrol \\
\hline Skor Ideal & 100 & 100 & 100 & 100 \\
\hline Skor Tertinggi & 55 & 50 & 85 & 70 \\
\hline Skor Terendah & 15 & 10 & 40 & 35 \\
\hline Rata-rata & 35,9 & 32,5 & 67,06 & 53,22 \\
\hline Standar Deviasi & 11 & 8,9 & 11,8 & 8,8 \\
\hline
\end{tabular}

Berdasarkan serangkaian pengujian dan perhitungan, hasilnya dapat disimpulkan secara keseluruhan bahwa pencapaian kemampuan pemahaman konsep matematika siswa pada kelas eksperimen lebih baik dibandingkan dengan kelas kontrol, hasil perhitungan selengkapnya dapat dilihat seperti pada Tabel 4. 
Tabel 4

Rekapitulasi Hasil Analisis Uji Gain Kelas Eksperimen dan Kontrol

\begin{tabular}{|l|l|l|l|}
\hline \multirow{2}{*}{ No. } & \multirow{2}{*}{ Ukuran Statistik } & \multicolumn{2}{|c|}{ Nilai Statistik } \\
\cline { 3 - 4 } 1 & Jumlah skor gain & 17,86 & Kelas Kontrol \\
\hline 2 & Rerata gain & 0,48 & 11,07 \\
\hline 3 & Kriteria & Sedang & 0,3 \\
\hline
\end{tabular}

Untuk mengetahui respon siswa dilakukan tes. Tes skala sikap atau kuesioner diberikan kepada salah satu sampel penelitian, yaitu sampel yang menjadi kelas eksperimen, kelas yang mendapatkan perlakuan khusus dalam proses pembelajarannya, yaitu pembelajaran matematika dengan pembelajaran kooperatif tipe Teams Geams Tournaments.

Setelah proses pembelajaran matematika dengan pembelajaran kooperatif tipe Teams Geams Tournaments dilaksanakan, selanjutnya siswa diberikan angket untuk mengetahui respon siswa terhadap proses pembelajaran yang telah dilaksanakan.

Berdasarkan perhitungan yang telah dilaksanakan diperoleh nilai rerata skor subjek dari angket skala sikap tersebut adalah $\geq 3$ yaitu $3,8 \approx$ 4. Hasil tersebut menunjukan bahwa siswa merespon baik dan berpendapat positif terhadap pembelajaran matematika dengan pembelajaran kooperatif tipe Teams Geams Tournaments.

Dengan demikian pembelajaran dengan kooperatif tipe TGT adalah salah satu metode pembelajaran alternatif yang dapat digunakan untuk pencapaian kemampuan pemahaman konsep matematika siswa khususnya pada Standar Kompetensi Geometri dan Pengukuran, menentukan unsur, bagian lingkaran serta ukurannya dan menghitung panjang garis singgung persekutuan dua lingkaran.

\section{Kesimpulan}

Berdasarkan hasil penelitian, ada beberapa hal yang dapat disimpulkan diantaranya adalah :

1. Pencapaian kemampuan pemahaman konsep matematika siswa yang mendapatkan pembelajaran kooperatif tipe 
Teams Geams Tournaments lebih baik daripada siswa yang memperoleh pembelajaran konvensional.

2. Peningkatan pemahaman konsep matematika siswa yang mendapatkan pembelajaran matematika dengan model kooperatif tipe Teams Geams Tournaments lebih baik dibandingkan dengan kemampuan pemahaman konsep matematika siswa yang mendapatkan pembelajaran konvensional. Peningkatan pemahaman konsep matematika siswa yang memperoleh pembelajaran kooperatif tipe TGT termasuk dalam kategori sedang, sedangkan siswa yang memperoleh pembelajaran konvensional peningkatannya termasuk dalam kategori rendah.

3. Berdasarkan hasil analisis respon siswa setelah pembelajaran terhadap model pembelajaran kooperatif tipe Teams Geams Tournaments yang telah dilaksanakan, menunjukan bahwa siswa merespon baik dan bersikap positif terhadap pembelajaran matematika dengan pembelajaran kooperatif tipe Teams Geams Tournaments.

\section{DAFTAR PUSTAKA}

Arikunto, S. (1998). Prosedur Penelitian Suatu Pendekatan Praktik. Jakarta: PT. Rineka Cipta.

Azwar, S. (2000). Sikap Manusia:Teori dan Pengukurannya. Jogjakarta: Pustaka Belajar.

Bied, M. (2011). Definisi Pemahaman Konsep Menurut Para Ahli.[Online]

Tersedia: www.MasBied.com.html. [27/11/2011 pkl.20:21].

Dahar, R.W. (1996). Teori-teori Belajar. Jakarta: Erlangga

Depdiknas. (1994). Standar Kompetensi, Mata Pelajaran Matematika Sekolah Menengah Pertama dan Madrasah Tsanawiyah. Jakarta: Depdiknas Herdian. (2010). Kemampuan Penalaran Matematika. [Online]. Tersedia:

http://herdy07.wordpress.com/ta g/kemampuan-penalaranmatematika/. Html. [2011/11/27 pkl 20:30]

Kiranawati. (2007). Model Pembelajaran ARIAS. [Online]. Tersedia:

grupkn.wordpress.com/2007/12/22/m odel-pembelajaran-arias/-78k. Html [20 Februari 2012]

Mulyani, S.R. (2006). Pembelajaran Matematika melalui Pembelajaran Kooperatif dengan Metode Teams-Geams- 
Tournaments dalam Upaya Meningkatkan Kemampuan Komunikasi Matematika Siswa. STKIP Subang: tidak diterbitkan.

Nasrudin, E. (2008). Psikologi Pembelajaran. UIN Sunan Gunung Djati: Bandung

Nasution. (2006). Metoda Research (Penelitian IImiah). Jakarta: Bumi Aksara
Slavin, E.R. (2009). Cooperative Learning Teori, Riset dan Praktik. Bandung: Nusa Media.

Sudjana. (2005). Metoda Statistika. Bandung: PT. Tarsito Bandung.

Sukjaya dan Suherman. (1990). Evaluasi Matematika. Pendidikan Wijayakusumah. 